\title{
Tallgrass Prairie Plant Community Dynamics Along a Canopy Cover Gradient of Eastern Redcedar (Juniperus virginiana L.)
}

\author{
Ryan F. Limb, ${ }^{1}$ David M. Engle, ${ }^{2}$ Aaron L. Alford, ${ }^{3}$ and Eric C. Hellgren ${ }^{4}$ \\ Authors are ${ }^{1}$ Senior Research Specialist and ${ }^{2}$ Professor, Department of Natural Resource Ecology and Management, Oklahoma State University, \\ Stillwater, OK 74078, USA; and ${ }^{3}$ Graduate Student and ${ }^{4}$ Professor, Cooperative Wildlife Research Laboratory, Southern Illinois University Carbondale, \\ Carbondale, IL 62901, USA.
}

\begin{abstract}
North American grasslands make up less than $75 \%$ of their historic pre-European settlement area, and they continue to be converted to woodlands by woody plant encroachment. Conversion of grassland to woodland alters nutrient cycling, water use, and light penetration, which drives herbaceous plant community dynamics. Because studies examining this relationship among Juniperus species are limited largely to individual trees, we designed a study to examine the relationship between stand-level canopy cover of eastern redcedar (Juniperus virginiana L.) and the herbaceous plant community. We documented herbaceous plant species composition, abundance, and biomass within a North American tallgrass prairie invaded by eastern redcedar in which canopy cover of eastern redcedar ranged from $0 \%$ to $80 \%$. Herbaceous species richness declined as a function of increased canopy cover of eastern redcedar and subsequent loss of open space, but this decrease in species richness closely followed a species-area model. Moreover, composition of $\mathrm{C}_{3}$ and $\mathrm{C}_{4}$ grasses and forbs did not change with increasing canopy cover. Herbaceous biomass, which declined with increasing canopy cover, varied most within those plots with intermediate canopy cover. While we found that species richness and biomass declined as canopy cover increased, the decline followed a species-area relationship and was without abrupt change typical of ecological thresholds. We recommend additional research with removal of eastern redcedar trees over a range of canopy cover to assess restoration potential along the encroachment gradient.
\end{abstract}

\section{Resumen}

Las praderas de América del Norte comprenden menos del $75 \%$ de su área histórica previa a la ocupación europea, y continúa su conversión a vegetación de monte debido a la expansión de plantas leñosas. La conversión de praderas a montes altera el ciclado de nutrientes, el uso del agua, y la penetración de luz, que determinan la dinámica de las comunidades herbáceas. Dado que los estudios que examinan esta relación entre especies de Juniperus están limitados mayormente a árboles individuales, diseñamos un ensayo para estudiar la relación entre cobertura de canopeo a nivel del monte de Juniperus virginiana L. y la comunidad herbácea. Documentamos la composición florística del estrato herbáceo, abundancia y biomasa en una pradera de pastos altos de América del Norte invadida por J. virginiana en la que la cobertura de dosel de J. virginiana fue de $0 \%$ al $80 \%$. La riqueza de especies herbáceas declinó en función de un incremento en la cobertura de dosel de J. virginiana y la pérdida subsecuente de espacio abierto, pero esta reducción en riqueza de especies mostró un alto grado de aproximación a un modelo de área-número de especies. Además, la composición de pastos $\mathrm{C}_{3}$ y $\mathrm{C}_{4}$ y de hierbas no varió ante incrementos de la cobertura de dosel. La biomasa herbácea, que declinó a medida que aumentó la cobertura de dosel, mostró la mayor variación en las parcelas con cobertura de dosel intermedias. Si bien encontramos que la riqueza de especies y la biomasa declinaron a medida que aumentó la cobertura de dosel, la reducción se aproximó a una relación de área-número de especies y no mostró cambios abruptos característicos de los umbrales ecológicos. Recomendamos investigación adicional con la remoción de J. virginiana a lo largo de un rango de cobertura de dosel para evaluar el potencial de restauración a lo largo de un gradiente de invasión de esta especie.

Key Words: emergent property, hierarchy theory, juniper, species-area relationships, threshold, woody encroachment

\section{INTRODUCTION}

North American grasslands are substantially reduced from their historic pre-European settlement size, primarily because of cultivation (Samson and Knopf 1994), and they continue to decline in area in part because of woody encroachment, a widely documented global phenomenon (Archer 1994; Van Auken 2000; Grant et al. 2004). Encroachment by eastern redcedar (Juniperus virginiana L.) converts Great Plains prairie into woodland in a matter of decades (Bragg and Hulbert Correspondence: Ryan F. Limb, 008c Agricultural Hall, Oklahoma State University, Stillwater, OK
74078, USA. Email: ryan.limb@okstate.edu

Manuscript received 5 May 2009; manuscript accepted 6 June 2010.
1976), altering biological features (Coppedge et al. 2002; Hoch et al. 2002; Chapman et al. 2004) and the abiotic environment (Norris et al. 2001; Smith and Johnson 2004). Across taxa of juniper (Juniperus spp.), crowns of individual trees reduce light penetration and litter accumulation, alter soil properties, and suppress seed germination and herbaceous seedling establishment, ultimately influencing the understory plant community (Gehring and Bragg 1992; Fuhlendorf et al. 1997; Yager and Smeins 1999).

Most studies on the influence of juniper on the plant community have focused on fine-scale, individual tree-level effects of woody species encroachment into grassland ecosystems. Little bluestem (Schizachryium scoparium [Michx.] Nash) is replaced by Kentucky bluegrass (Poa pratensis L.) 
and Carex spp., thereby shifting composition from $\mathrm{C}_{4}$ midgrasses and tallgrasses to $\mathrm{C}_{3}$ midgrasses, shortgrasses, and sedges (Gehring and Bragg 1992). Species richness declines immediately under the crown of individual Ashe juniper trees (Juniperus ashei Buckholz; Fuhlendorf et al. 1997) and eastern redcedar trees (Briggs et al. 2002) compared to grassdominated interspaces. Reduced species richness and species compositional shifts are a reflection of reduced light penetration immediately under the tree crown (Fuhlendorf et al. 1997). In contrast, light penetration of conifers at the stand scale can be spatially heterogeneous, sufficient to meet the photosynthesis demand of some herbaceous species in the interspaces but insufficient to meet the photosynthesis demand of most herbaceous plants under tree crowns (Bartemucci et al. 2006). Therefore, stand-level species composition at various levels of eastern redcedar canopy cover, in contrast to species composition beneath individual tree crowns, is difficult to predict.

A useful theoretical model for this purpose is the species-area relationship (SAR), one of the oldest and most studied concepts addressing diversity patterns (Rosenzweig 1995). A fundamental principle of the SAR is that species richness increases as a function of increasing sampling area and decreases with decreased sampling area. The SAR can be used generally to predict the decrease or even the extinction of species as a function of the loss of habitat or suitable space, and SAR provides the basis for natural area and preserve design, disturbance implications, and species richness (MacArthur and Wilson 1967; Soulé et al. 1979; Palmer 1990; Lawrey 1991; Rosenzweig 1995). The SAR also depends on the relative amount of space sampled, with the association or pattern of area sampled less influential. This principle can be applied to woody species encroachment into grasslands, where a change in species richness could be expected to occur at a level predicted by the SAR.

Woody encroachment into grassland also generally reduces herbaceous production (Engle et al. 1987; Belksy 1994; Bates et al. 2000; Watson and Reid 2001), but herbaceous production does not always decline linearly with encroachment (Callaway 1995). Assessments of interactions between woody species and herbaceous production require species-by-species examination because of variation in canopy structure, nutrient uptake and release, and root:shoot ratio in tree and shrub species. Herbaceous biomass was up to $60 \%$ less in zones well beyond the drip line as compared to beyond the influence of the juniper tree in Arizona (Arnold 1964), and the effect has a nonlinear density dependent/biomass relationship (Short et al. 1977). Under dense stands of eastern redcedar, production decreased nearly 99\% compared to open grassland sites (Briggs et al. 2002). However, directly under the crown of individual eastern redcedar trees in semiarid and subhumid environments, production was greatly reduced but was unaffected beyond the drip line, suggesting that zones of influence of individual trees do not overlap (Engle et al. 1987).

Eastern redcedar encroachment also is likely to alter the spatial distribution of herbaceous production. Light available to the herbaceous layer at the stand level could be expected to decrease as canopy cover of eastern redcedar increases. However, a relatively homogeneous spatial distribution of abundant light at low stand-level canopy cover of eastern redcedar could be expected to result in low stand-level variability of herbaceous production. Similarly, a relatively homogeneous distribution of low light available to the herbaceous layer associated with high stand-level canopy cover could be expected to result in low stand-level variability of herbaceous production. Conversely, an uneven distribution of light at moderate levels of eastern redcedar canopy cover could be expected to result in highly variable herbaceous production.

Eastern redcedar encroachment creates heterogeneous environments because of the nonuniform distribution of individual trees and contrasting properties among individual tree crowns and open interspaces. Most ecological studies fail to consider this inherent heterogeneity in their conclusions and implications (Wu and Loucks 1995). In the context of hierarchy theory, where a scaled view of ecosystems reveals interacting components at multiple levels (O’Neill et al. 1989), patchy environments exhibit emergent properties that are more than the summation of individual characteristics and not necessarily predicted by the properties of the components. Vertical structure in a stand, for example, influences airflow across a landscape. Size, shape, and density of trees within a stand dictate micropatterns (direction and velocity) of wind through trees (Heisler and Dewalle 1988). This pattern differs from predictions that sum the effect of individual trees on microclimate, and its influence on plant community composition and production is linear.

Therefore, we designed a study to examine the relationship between stand-level eastern redcedar canopy cover and the herbaceous plant community, and our sampling design allowed us to investigate the relationship of canopy cover and standlevel heterogeneity. We predict an additive effect on plant community properties (species composition and herbaceous biomasss) as trees are added to the stand because the effect of a tree is limited to beneath the tree crown (not beyond the crown; Engle et al. 1987). We hypothesized that 1) herbaceous species richness declines along the eastern redcedar canopy cover gradient but at a level predicted by the SAR; 2) species loss (predicted in item 1) is greater among the $\mathrm{C}_{4}$ graminoid and forb species groups than the $\mathrm{C}_{3}$ graminoid species group, as suggested by Gehring and Bragg (1992); 3) herbaceous biomass will decline at a linear rate along the eastern redcedar canopy gradient; and 4) stand-level variation in herbaceous biomass will be in the form of a unimodal distribution along the gradient with peak variance at midlevel canopy cover of eastern redcedar. We addressed these hypotheses in terms of both increasing eastern redcedar canopy cover and decreasing open space.

\section{METHODS}

We conducted this experiment in tallgrass prairie located about $18 \mathrm{~km}$ southwest of Stillwater, Oklahoma, USA (lat $36^{\circ} 06^{\prime} \mathrm{N}$, long $\left.97^{\circ} 23^{\prime} \mathrm{W}\right)$. The region is dominated by a continental climate with an average of 204 frost-free days and $846 \mathrm{~mm}$ annual precipitation, $65 \%$ of which falls from May to October (Meyers 1982). Typical climax vegetation in the study area is characterized by little bluestem, indiangrass (Sorghastrum nutans [L.] Nash), switchgrass (Panicum virgatum L.), big bluestem (Andropogon gerardii Vitman), Carex spp., and perennial forbs. We selected $14100 \times 100 \mathrm{~m}$ locations on 
the shallow prairie ecological site (US Department of Agriculture 2006) that had mixed grazing history but were mostly ungrazed in recent decades. Exceptions to this were abundant deer in one location and moderate yearlong cattle grazing (0.8 ha animal unit month $\left.{ }^{-1}\right)$ at a second location. Eastern redcedar canopy cover on our study locations ranged between $0 \%$ and $77 \%$ as determined by aerial photographs and ground verification with a densitometer of 50 points at each location. A $49 \times 49 \mathrm{~m}$ plot was established at each location with a buffer of similar vegetation around the perimeter. Within each $49 \times$ $49 \mathrm{~m}$ plot, permanent grids were established with 16 evenly spaced sampling points within which we estimated midsummer herbaceous species composition and abundance using a $1 \times 1 \mathrm{~m}$ sampling frame. Several plants were identified only to genus. Plant species canopy cover and bare ground were estimated with cover classes $(0-1 \%,>1-5 \%,>5-25 \%,>25-50 \%$, $>50-75 \%,>75-95 \%$, and $>95-100 \%)$. The midpoint value of each class was used in analyses. A mean cover value was calculated for each species among the 16 sampling points to determine plot-level plant species abundance.

To estimate species accumulation in the absence of eastern redcedar, species-area curves were constructed using the list of species from each of the 16 sampling points within the two plots that had no eastern redcedar (i.e., $0 \%$ canopy cover of eastern redcedar). The order in which we organized the 16 frames was chosen randomly using a random number generator and repeated eight times before averaging species accumulation for the two locations. We used regression to fit the relationship between species richness and area sampled, and we chose the best model using the Akaike information criterion (AIC; Burnham and Anderson 1998). We used this curve as the standard to compare species richness as a function of eastern redcedar canopy cover.

Detrended correspondence analysis (Hill and Gauch 1980) was used to analyze plot-level plant species composition. The data were square-root transformed, and the influence of rare species was down-weighted in the ordination analysis. Eastern redcedar canopy cover was treated as a supplemental variable, which does not constrain the analysis, to visually assess the relationship between eastern redcedar canopy cover and plant species composition. Because of the mixed grazing history among study locations, grazing was initially included in the analysis as a supplemental variable. However, less than $1 \%$ of the plant community composition was explained by grazing; therefore, it was not included in subsequent analyses.

We estimated herbaceous biomass in each plot using visual obstruction (i.e., Robel pole) at 90 evenly spaced points (Robel et al. 1970). We calibrated visual obstruction data by clipping to soil level the herbaceous vegetation at 150 sampling points that encompassed a wide range of visual obstruction and then oven dried these samples to a constant weight before weighing. Linear regression was used to determine the relationship between visual obstruction and herbaceous biomass (Vermeire and Gillen 2001; Higgins et al. 2005; Limb et al. 2007). The resulting equation was $y=$ $11.56 x+13.97 ; r^{2}=0.78 ; P=0.038$, in which $x$ is visual obstruction and $y$ is biomass in $\mathrm{kg} \cdot \mathrm{ha}^{-1}$. We subsequently expressed standing herbaceous biomass and the within-plot variance of biomass as a function of canopy cover of eastern

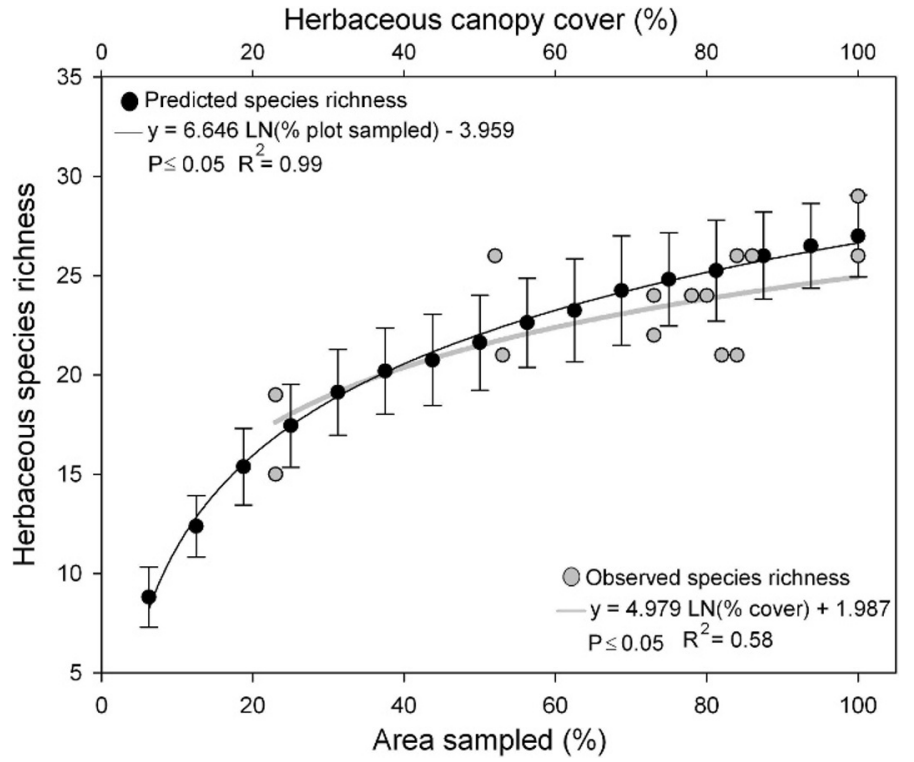

Figure 1. Species richness predicted from a species-area relationship (dark line and solid black circles; bars are one standard error) constructed from sampling $161-\mathrm{m}^{2}$ quadrats in two $49 \times 49$ m study plots that contained no eastern redcedar. Observed species richness (gray circles and gray line) in $49 \times 49 \mathrm{~m}$ plots within tallgrass prairie invaded by eastern redcedar. Herbaceous canopy cover is the inverse of eastern redcedar canopy cover.

redcedar and chose the lowest-order polynomial, best-fitting model using AIC model selection.

\section{RESULTS}

We examined herbaceous species data using only those observations from the two plots void of eastern redcedar to construct the SAR for this tallgrass prairie. Herbaceous species richness increased with increased sampling area from an average of nearly nine species at $6 \%$ of the sampled area $\left(1 \mathrm{~m}^{2}\right)$ to 27 species at $100 \%$ of the sampled area $\left(16 \mathrm{~m}^{2}\right.$; Fig. 1). The data fit a logarithmic SAR $\left(r^{2}=0.99\right)$ of accumulating species with increments of increasing area sampled.

We used the constructed SAR as a model to predict the rate at which observed species richness would decline as open space decreases. When we examined the influence of increasing eastern redcedar canopy cover, species richness declined from 23 species at $14 \%$ canopy cover to 17 species at $77 \%$ canopy cover (Fig. 1). However, this decline in richness tracks closely the decline predicted by the SAR and indicates that declines in species richness associated with eastern redcedar encroachment result from diminishing area not covered by eastern redcedar.

Species within the $\mathrm{C}_{4}$ graminoid, $\mathrm{C}_{3}$ graminoid, and forb species groups declined at the same rate across the gradient of eastern redcedar canopy cover $(P>0.05$; Fig. 2$)$. We recorded 61 individual species or genera among the 14 locations, of which 39 were forbs, 17 were $\mathrm{C}_{4}$ graminoids, and 5 were $\mathrm{C}_{3}$ graminoids. Abundance of individual species varied from location to location and did not consistently change along the eastern redcedar canopy gradient, which is reflected in the 


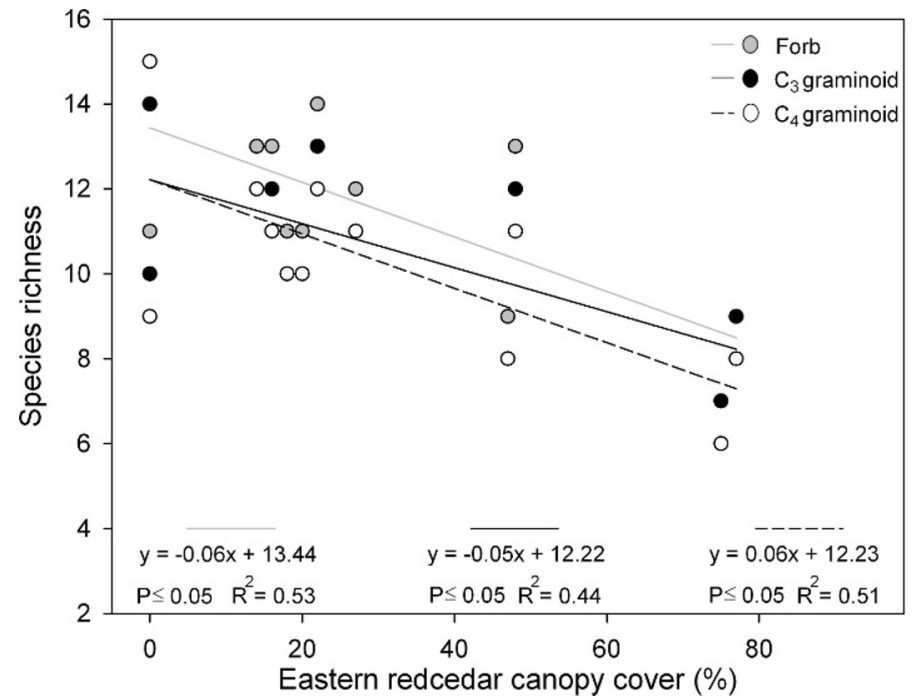

Figure 2. Species richness as a function of canopy cover of eastern redcedar within tallgrass prairie. Species richness is grouped into forbs, $\mathrm{C}_{3}$ grasses, and $\mathrm{C}_{4}$ grasses.

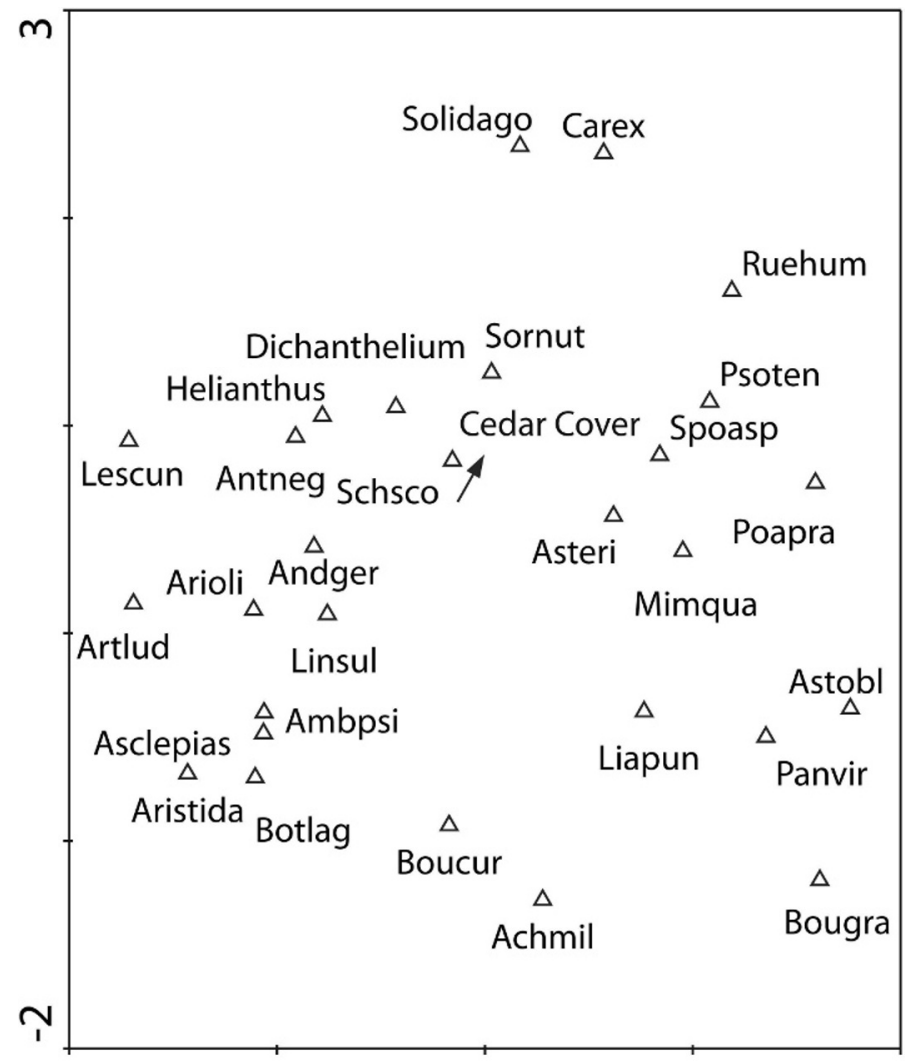

$-1$

3

Figure 3. Scatter plot of the detrended correspondence analysis axis 1 and axis 2 of plot-level herbaceous species abundance along a gradient of canopy cover of eastern redcedar within tallgrass prairie. Abbreviated species notation includes either the first three letters from the genus and specific epithet or the genus name. Species with $<2 \%$ canopy cover are not shown in the figure. Ordination eigenvalues and cumulative variance were 0.35 and 18.1, respectively, for axis 1 and 0.41 and 39.1, respectively, for axis 2 . Variation explained by canopy cover of eastern redcedar was $8.7 \%$ among all axes.

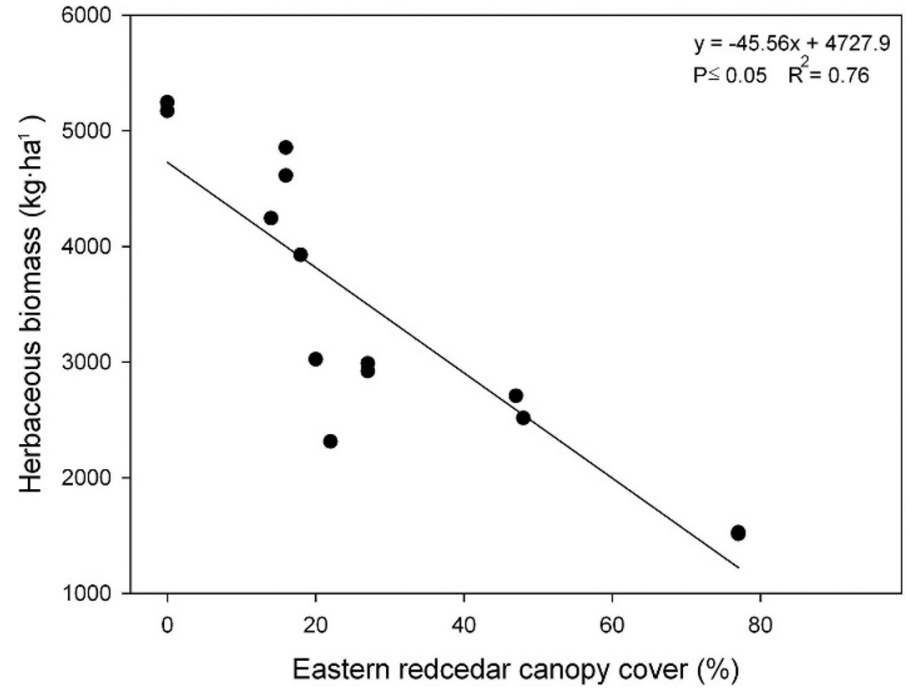

Figure 4. Plot-level herbaceous biomass as a function of eastern redcedar canopy cover in tallgrass prairie.

ordination, which shows no strong relationship between individual species and canopy cover of eastern redcedar (Fig. 3). Species evenness lacked a strong relationship $\left(r^{2}=0.02 ; P<0.05\right)$ with the gradient in eastern redcedar canopy cover (data not shown).

Herbaceous biomass decreased at a linear rate from about $5300 \mathrm{~kg} \cdot \mathrm{ha}^{-1}$ with $0 \%$ eastern redcedar canopy cover to about $1500 \mathrm{~kg} \cdot \mathrm{ha}^{-1}$ with $77 \%$ canopy cover (Fig. 4), which is a $460 \mathrm{~kg} \cdot \mathrm{ha}^{-1}$ decline in herbaceous biomass with each $10 \%$ increase in canopy cover. As we predicted, variation in biomass along the canopy gradient followed a unimodal distribution with a peak in variance at intermediate canopy cover of eastern redcedar (Fig. 5). The standard deviation for herbaceous biomass was relatively small at both low and high levels of canopy cover ( $\mathrm{SD}=198$ and 215 , respectively) and greatest $(\mathrm{SD}=550)$ at intermediate canopy cover of eastern redcedar.

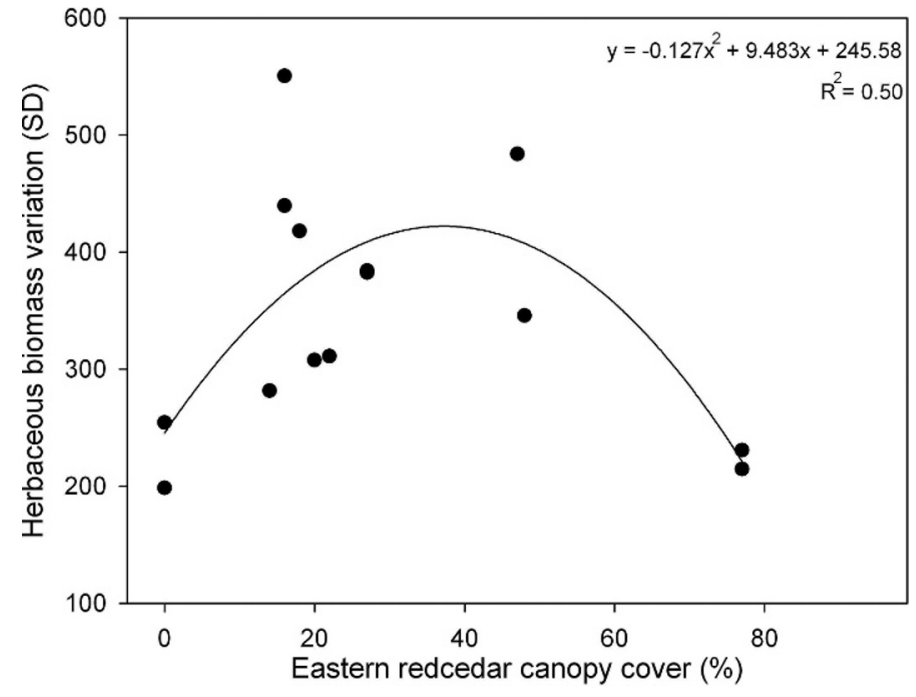

Figure 5. Plot-level variation (SD) in herbaceous biomass as a function of eastern redcedar canopy cover in tallgrass prairie. 


\section{DISCUSSION}

Research on the effects of eastern redcedar encroachment on tallgrass prairie plant communities has focused primarily on the effects of the individual tree. The effects of other species of juniper have similarly focused on the sphere of influence of individual trees. In this study, we evaluated stand-level plant herbaceous community dynamics to increasing levels of encroachment, which for a variety of reasons cannot be assumed to follow as an additive effect of individual trees. That is, in keeping with hierarchy theory, emergent properties often emerge that cannot be predicted with an additive model (O’Neill et al. 1989).

We found that herbaceous species richness declined as a function of increased canopy cover and the resulting loss of open space. Moreover, species richness declined in a pattern reflecting the SAR. Our results contrast with previously reported response of species richness to increasing density of eastern redcedar trees (Briggs et al. 2002) in which richness decreases rapidly as trees become dense. Woody encroachment into tallgrass prairie eventually reduces herbaceous species richness by as much as 90\% (Briggs et al. 2002; Lett and Knapp 2005). Herbaceous species richness declined from about 27 species $\cdot 10 \mathrm{~m}^{-2}$ at 0 eastern redcedar trees $\cdot \mathrm{ha}^{-1}$ to 5 species $10 \mathrm{~m}^{-2}$ at about 1500 eastern redcedar trees $\cdot \mathrm{ha}^{-1}$ (Briggs et al. 2002). We believe our study across a gradient of eastern redcedar canopy cover more adequately addresses species richness as a function of increasing canopy cover of eastern redcedar, and we reason that the response reflects results of previous research that showed that the impact of eastern redcedar, while substantial, is limited to the area directly beneath the crown of individual trees (Engle et al. 1987; Gehring and Bragg 1992). Therefore, the influence of eastern redcedar trees at the stand level is the summation of individual trees. That is, as additional trees are added to the stand and displace open space, an equivalent level of herbaceous plant species are displaced, consistent with the effect predicted by the SAR. Even though others have explained extra-additive effects of additional trees at the stand level as resulting from increased heterogeneity (e.g., Heisler and Dewalle 1988), we found no evidence for this phenomenon in tallgrass prairie.

Our results contrast with previous research that noted differential effects of woody plant encroachment on groups of species such as C3 and C4 graminoids. Herbaceous species abundance, richness, and evenness and species richness within three functional groups all declined uniformly along the gradient of eastern redcedar canopy cover. In our second hypothesis, we predicted that $\mathrm{C}_{4}$ graminoid and forb species groups would decline more rapidly than the $\mathrm{C}_{3}$ graminoid group. We based this prediction on three studies in tallgrass prairie about $325-550 \mathrm{~km}$ north of our study area. Kentucky bluegrass and Carex spp. were more abundant in the shaded area directly beneath the crown of individual eastern redcedar trees than in the interspaces between trees in eastern Nebraska (Gehring and Bragg 1992) and the Flint Hills of northeastern Kansas (Briggs et al. 2002). In the center of islands of roughleaf dogwood (Cornus drummondii C.A. Mey.), an encroaching woody shrub in the Flint Hills of northeastern Kansas, forb cover was greater than on adjacent open sites that lacked roughleaf dogwood (Lett and Knapp 2005). Just as forest canopies intercept vast quantities of incoming solar radiation, preventing much of the light from reaching the canopy of the understory plant community, woody species that encroach into grassland similarly reduce light available to understory prairie species (Scholes and Archer 1997; Siemann and Rogers 2003). However, forest canopies do not intercept the incoming solar radiation uniformly and influence the quality of light by allowing differing wavelengths to pass depending on composition of canopy species (Freyman 1968). The quantity and quality of light penetrating the tree canopy can alter the understory plant composition (Haugo and Halpern 2007). Our study indicates that the canopy influence of eastern redcedar on light quantity and quality is limited to beneath individual tree crowns.

Ordination of the species composition data also supports arrangement of species independent of canopy cover of eastern redcedar. Eastern redcedar seeds and seedlings are distributed randomly across the landscape except for increased abundance near perch sites of frugivorous birds (Holthuijzen and Sharik 1984). As a result, one might expect the absence of herbaceous species directly beneath individual tree crowns (Gehring and Bragg 1992) to result in random displacement of species at the stand level, and this may explain why we observed no shift in species group abundance along the gradient of eastern redcedar canopy cover. Even at high levels of canopy cover, sufficient patches of open space remain to support characteristic prairie species. We conclude that the resulting assemblage of herbaceous plant species is more a product of individual site characteristics (soil, slope, fire, grazing, and so on) than of eastern redcedar canopy cover.

Our results confirm that eastern redcedar trees do not influence the plant community beyond the boundary of the tree crown, nor does the altered environment beneath the tree favor one group of herbaceous plants over another. Roots of individual trees of junipers in more arid environments extend well beyond the drip line and transport nutrients back to the tree center and ultimately into the stems and leaves, suppressing herbaceous plant growth beyond the canopy. In tallgrass prairie, light is often more limiting to herbaceous biomass production than water (Knapp et al. 1998). In contrast, water limits annual net primary production (ANPP) more than light availability in more arid environments, where roots extending beyond the drip line can compete for limited water resources and affect surrounding vegetation. As a result, the magnitude of effect often increases with increased juniper cover in arid landscapes (Clary 1974; Pieper 1990). Conversely, in environments where light is often more limiting than water, reduced light due to tree canopies strongly influences herbaceous biomass, but the magnitude of effect is not greater with increased canopy cover. This relationship is consistent in our study with a linear biomass decline with increased canopy cover.

Alligator juniper (Juniperus deppana) influences vegetation in an area over three times larger than the tree crown (Clary 1974). One-seeded juniper (Juniperus monosperma) suppresses vegetation nearly $5 \mathrm{~m}$ beyond the canopy but increases production at the drip line (Arnold 1964). Even though research is lacking in these species at the stand level, this effect is less likely to be pronounced at the stand scale, where multiple root masses overlap and compete for the same resources. 
Because eastern redcedar, like other woody plants, influences litter depth, soil moisture, nitrogen availability, and soil biota beneath the tree crown, we expected eastern redcedar also to strongly influence herbaceous plant species composition, a common response to woody plants (Griffiths et al. 2005; Haugo and Halpern 2007). Moreover, nutrients leached from leaf litter beneath the tree create relatively fertile areas known as islands of fertility (Hibbard et al. 2001). A few grasses and forbs, especially grasses with the $\mathrm{C}_{3}$ photosynthetic pathway, grow and reproduce vigorously in this fertile soil. In contrast, eastern redcedar, unlike other North American junipers, does not produce fertile and unfertile zones extending beyond the tree; rather, the influence on vegetation is limited to directly under the canopy (Engle et al. 1987; Engle and Kulbeth 1992). Therefore, we saw no compositional shift at the stand level with our study. Herbaceous biomass decreased in proportion to increasing canopy cover of eastern redcedar, but variation in biomass was maximized at an intermediate level of canopy cover. These results support our third and fourth hypotheses that predicted a linear decline in herbaceous biomass along an eastern redcedar canopy gradient and a unimodal distribution of biomass variation. These results are not surprising since herbaceous ANPP is $99 \%$ less under the crowns of isolated trees as compared to interspaces in tallgrass prairie (Engle et al. 1987; Briggs et al. 2002) and because the influence of eastern redcedar is limited to the area immediately beneath the crown (Engle et al. 1987; Gehring and Bragg 1992) unlike juniper species with large zones of influence in more arid environments (Arnold 1964; Short et al. 1977). In fact, eastern redcedar (Norris et al. 2001) and roughleaf dogwood (Lett and Knapp 2005) encroaching into tallgrass prairie shift biomass from herbaceous to woody plants even though they do not decrease total ecosystem biomass production.

\section{MANAGEMENT IMPLICATIONS}

This study is relevant to ecosystems not in equilibrium and particularly to grasslands experiencing woody encroachment. The concept of ecological thresholds (Holling 1973; Westoby et al. 1989) provides a framework for understanding change in ecosystems not at equilibrium. Through excessive negative feedback mechanisms, nonequilibrium ecosystems can transition through a series of degenerative thresholds and transitions. The stepwise process ultimately leads to a new state with a substantially different function than the original ecosystem (Briske et al. 2006). Grasslands cross the initial structure threshold when low density of trees or shrubs alters natural disturbance patterns, which promotes additional woody encroachment, often leading to a species richness threshold. However, the species richness threshold is inconsistent among woody species. Studies in the North American West (Blackburn and Tueller 1970; Miller et al. 2000) and Southwest (Archer 1989) reported that the species richness threshold was crossed at intermediate levels of woody encroachment. We found that species richness in tallgrass prairie declined as a function of increasing canopy cover of eastern redcedar in a manner predicted by the SAR rather than an abrupt shift in species richness occurring at a narrow range of canopy cover of eastern redcedar. Evidence for a species richness threshold with encroachment of eastern redcedar was previously limited to a single study in tallgrass prairie of northeastern Kansas in which the comparison was with open prairie and prairie with a high level of canopy cover of eastern redcedar (Briggs et al. 2002). An important implication of the ecological threshold concept is that returning tallgrass prairie invaded by eastern redcedar to a prairie state requires either high levels of anthropogenic inputs or time exceeding a management time line. Our results suggest that removing eastern redcedar trees from tallgrass prairie with up to about $75 \%$ canopy cover of eastern redcedar will allow restoration to tallgrass prairie since a profound change in species composition was not observed at any point along the encroachment gradient. Therefore, we recommend additional research with removal of eastern redcedar trees over a range of canopy cover to assess restoration potential along the encroachment gradient.

\section{ACKNOWLEDGMENTS}

This research was funded by the Oklahoma Agricultural Experiment Station and the Oklahoma State University Department of Natural Resource Ecology and Management. We thank C. Stansberry, J. Weir, and numerous technicians for assistance with various aspects of this study.

\section{LITERATURE CITED}

ARCHER, S. 1989. Have southern Texas savannas been converted to woodlands in recent history? The American Naturalist 134:543-561.

ARCHER, S. 1994. Woody plant encroachment into southwestern grasslands and savannas: rates, patterns and proximate causes. In: M. Vavra, W. A. Laycock, and R. D. Piper [EDS.]. Ecological implications of livestock herbivory in the west. Denver, C0, USA: Society for Range Management. p. 13-68.

ARnold, J. F. 1964. Zonation of understory vegetation around a juniper tree. Journal of Range Management 17:41-42.

Bartemucci, P., C. Messier, and C. D. Canham. 2006. Overstory influences on light attenuation patterns and understory plant community diversity and composition in southern boreal forests of Quebec. Canadian Journal of Forest Resources 36:2065-2079.

Bates, J. D., R. F. Miller, and T. J. Svejcar. 2000. Understory dynamics in cut and uncut western juniper woodlands. Journal of Range Management 53:119-126.

Belsky, A. J. 1994. Influences of trees on savanna productivity-tests of shade, nutrients, and tree-grass competition. Ecology 75:922-932.

Blackburn, W. H., and P. T. Tueller. 1970. Pinyon and juniper invasion in black sagebrush communities in eat-central Nevada. Ecology 51:841-848.

BragG, T. B., And L. C. Hulbert. 1976. Wood plant invasion of unburned Kansas bluestem prairie. Journal of Range Management 29:19-24.

Briggs, J. M., G. A. Hoch, And L. C. Johnson. 2002. Assessing the rate, mechanisms, and consequences of the conversion of tallgrass prairie to Juniperus virginiana forest. Ecosystems 5:578-586.

Briske, D. D., S. D. Fuhlendorf, and F. E. Smeins. 2006. A unified framework for assessment and application of ecological thresholds. Rangeland Ecology \& Management 59:225-236.

BuRnham, K. P., and D. R. Anderson. 1998. Model selection and inference: a practical information-theoretic approach. New York, NY, USA: Springer-Verlag. $353 \mathrm{p}$.

Callaway, R. M. 1995. Positive interactions among plants. Botany Review 61:306-349.

Chapman, R. N., D. M. Engle, R. E. Masters, and D. M. Leslie, JR. 2004. Tree invasion constrains the influence of herbaceous structure in grassland bird habitats. Écoscience 11:55-63. 
ClaRY, W. P. 1974. Response of herbaceous vegetation to felling of alligator juniper. Journal of Range Management 27:387-389.

Coppedge, B. R., D. M. Engle, R. E. Masters, and M. S. Gregory. 2001. Avian response to landscape change in fragmented Southern Great Plains grasslands. Ecological Applications 11:47-59.

EngLE, D. M., AND J. D. KuLBETH. 1992. Growth dynamics of crown of eastern redcedar at three locations in Oklahoma. Journal of Range Management 45:301-305.

Engle, D. M., J. F. Stritzke, and P. L. Claypool. 1987. Herbage standing crop around eastern redcedar trees. Journal of Range Management 40:237-239.

Freyman, S. 1968. Spectral distribution of light in forests of the Douglas-fir zone of southern British Columbia. Canadian Journal of Plant Science 48:326-328.

FuHLendorf, S. D., F. E. Smeins, And C. A. TAYloR. 1997. Browsing and tree size influences on Ashe juniper understory. Journal of Range Management 50:507-512.

Gehring, J. L., And T. B. BragG. 1992. Changes in prairie vegetation under eastern red cedar (Juniperus virginiana L.) in an eastern Nebraska bluestem prairie. The American Midland Naturalist 128:209-217.

Grant, T. A., E. Madden, and G. B. Berkey. 2004. Tree and shrub invasion in northern mixed-grass prairie: implications for breeding grassland birds. Wildlife Society Bulletin 32:807-818.

Griffiths, A. D., H. J. Schult, And J. Gorman. 2005. Wild harvest of Cycas arnhemica (Cycadaceae): impact on survival, recruitment and growth in Arnhem Land, northern Australia. Australian Journal of Botany 53:771-779.

Haugo, R. D., and C. B. Halpern. 2007. Vegetation response to conifer encroachment in a western Cascade meadow: a chronosequence approach. Canadian Journal of Botany 85:285-298.

Heisler, G. M., and D. R. Dewalle. 1988. Effects of windbreak structure on wind flow. Agriculture, Ecosystems and Environment 22/23:41-69.

Hibbard, K. A., S. Archer, D. S. Schimel, and D. W. Valentine. 2001. Biogeochemical changes accompanying woody plant encroachment in a subtropical savanna. Ecology 82:1999-2011.

Higins, K. F., K. J. Jenkins, G. K. Clambey, D. W. Uresk, D. E. Naugle, J. E. Norland, AND W. T. BARKER. 2005. Vegetation sampling and measurement. In: C. E. Braun [ED.]. Techniques for wildlife investigations and management. 6th ed. Bethesda, MD, USA: The Wildlife Society. p. 524-553.

HiLL, M. O., AND G. G. GAuCH, JR. 1980. Detrended correspondence analysis: an improved ordination technique. Vegetatio 42:47-58.

Hoch, G. A., J. M. BRiggs, AND L. C. Johnson. 2002. Assessing the rate, mechanisms, and consequences of the conversion of tallgrass prairie to Juniperus virginiana forest. Ecosystems 5:578-586.

Holuıng, C. S. 1973. Resilience and stability of ecological systems. Annual Review of Ecology and Systematics 4:1-23.

Holthuluzen, A. M. A., and T. L. Sharik. 1984. Seed longevity and mechanisms of regeneration of eastern redcedar (Juniperus virginiana L.). Bulletin of the Torrey Botanical Club 111:153-158.

Knapp, A. K., J. M. Briggs, J. M. BlaiR, and C. L. Turner. 1998. Patterns and controls of aboveground net primary production in tallgrass prairie. In: A. K. Knapp, J. M. Briggs, D. C. Hartnett, and S. L. Collins [EDS.]. Grassland dynamics: longterm ecological research in tallgrass prairie. New York, NY, USA: Oxford University Press. p. 193-221.

LaWREY, J. D. 1991. The species-area curve as an index of disturbance in saxicolous lichen communities. Bryologist 94:377-382.

LetT, M. S., AND A. K. Knapp. 2005. Woody plant encroachment and removal in mesic grassland: production and composition responses of herbaceous vegetation. The American Midland Naturalist 153:217-231.

Limb, R. F., K. R. Hickman, D. M. Engle, J. E. Norland, and S. D. Fuhlendorf. 2007. Digital photography: reduced investigator variation in visual obstruction measurements for southern tallgrass prairie. Rangeland Ecology \& Management 60:548-552.
MacArther, R. H., and E. O. Wilson. 1967. The theory of island biography. Princeton, NJ, USA: Princeton University Press. 203 p.

Meyers, H. R. 1982. Climatological data of Stillwater, Oklahoma 1893-1980. Stillwater, OK, USA: Oklahoma Agriculture Experiment Station. Research Report P-821. $36 \mathrm{p}$.

Miller, R. F., T. J. Svejcar, and J. A. Rose. 2000. Impacts of western juniper on plant community composition and structure. Journal of Range Management 53:574-585

Norris, M. D., J. M. Blair, L. C. Johnson, and R. B. McKane. 2001. Assessing changes in biomass, productivity, and $\mathrm{C}$ and $\mathrm{N}$ stores following Juniperus virginiana forest expansion into tallgrass prairie. Canadian Journal of Forrest Resources 31:1940-1946.

O'Neill, R. V., A. R. Johnson, And A. W. King. 1989. A hierarchical framework for the analysis of scale. Landscape Ecology 3:193-205.

Palmer, M. W. 1990. The estimation of species richness by extrapolation. Ecology 71:1195-1198.

PIePER, R. D. 1990. Overstory-understory relations in pinyon-juniper woodlands in New Mexico. Journal of Range Management 43:413-415.

Robel, R. J., J. N. Briggs, A. D. Dayton, and L. C. Hulbert. 1970. Relationships between visual obstruction measurements and weight of grassland vegetation. Journal of Range Management 23:295-297.

Rosenzweig, M. L. 1995. Species diversity in space and time. New York, NY, USA: Cambridge University Press. 436 p.

Samson, F., and F. Knopf. 1994. Prairie conservation in North America. Bioscience 44:418-421.

Scholes, R. J., And S. R. Archer. 1997. Tree-grass interactions in savannas. Annual Review of Ecology and Systematics 28:517-544.

Short, H. L., W. Evans, and E. L. Boeker. 1977. The use of natural and modified pinyon pine-juniper woodlands by deer and elk. Journal of Wildlife Management 41:543-559.

Siemann, E., and W. E. Rogers. 2003. Changes in light and nitrogen availability under pioneer trees may indirectly facilitate tree invasions of grasslands. Journal of Ecology 91:923-931.

Smith, D. L., AND L. Johnson. 2004. Vegetation-mediated changes in microclimate reduce soil respiration as woodlands expand into grasslands. Ecology 85:3348-3361.

Soulté, M. E., B. A. Wilcox, And C. HoltBy. 1979. Benign neglect: a model of faunal collapse in the game reserves of East Africa. Biological Conservation 15:259-272.

US Department of Agriculture. 2006. Oklahoma ecological site descriptions. Available at: http://efotg.nrcs.usda.gov/references/public/OK/Range_sites_1006. pdf. Accessed 17 December 2007.

Van Auken, O. W. 2000. Shrub invasions of North American semi-arid grasslands. Annual Review of Ecology and Systematics 31:197-215.

VermelRe, L. T., and R. L. Gillen. 2001. Estimating herbage standing crop with visual obstruction in tallgrass prairie. Journal of Range Management 54:57-60.

Watson, C., And N. Reid. 2001. Herbage response to thinning of eucalypt regrowth. Natural Resource Management 4:16-21.

Westoby, B., B. H. WalkeR, and I. Noy-MeiR. 1989. Opportunistic management for rangelands not at equilibrium. Journal of Range Management 42:266-274.

Wu, J., AND 0. L. Loucks. 1995. From balance of nature to hierarchical patch dynamics: a paradigm shift in ecology. Quarterly Review of Biology 70:439-466.

Yager, L. Y., And F. E. Smeins. 1999. Ashe juniper (Juniperus ashei: Cupressaceae) canopy and litter effects on understory vegetation in a juniper-oak savanna. The Southwestern Naturalist 44:6-16. 